\title{
PERUBAHAN MASYARAKAT MELAYU DI KOTA MEDAN: SUATU KAJIAN TENTANG TRADISI MEMBANGUN RUMAH TINGGAL
}

\author{
Azmi $^{1 *}$, Adek Cerah Kurnia Azis ${ }^{2 *}$ \\ Program Studi Pendidikan Seni Rupa Jurusan Seni Rupa Fakultas Bahasa dan Seni \\ Universitas Negeri Medan \\ Jl. Willem Iskandar Pasar V Medan Estate, Kec. Percut Sei Tuan, Kab. Deli Serdang, Kode Pos 20371 \\ Sumatera Utara. Indonesia \\ Email: azmits991@gmail.com,adek_peros@yahoo.com
}

\begin{abstract}
Abstrak
Penelitian ini dilakukan untuk membuktikan perubahan masyarakat Melayu suatu kajian tradisi membangun rumah tinggal, di kota Medan Sumatera Utara. Penelitian memakai metode deskriptif kualitatif dengan desain etnometodologi dan etnosains, menggunakan subjek penelitian sebanyak 10 buah rumah panggung. Instrumen penelitian ini memakai teknik dokumentasi dan interview yang secara komprehensif ingin melihat fenomena budaya masyarakat Melayu di kota Medan, dalam kaitannya dengan tradisi membangun rumah tinggal. Hasil dari teknik analisis data yang digunakan model Miles dan Huberman menunjukkan bahwa perubahan bentuk rumah tinggal tradisional disebabkan oleh faktor adat Melayu yang memberikan keterbukaan dan keluwesan. Perubahan-perubahan masyarakat Melayu di kota Medan menyebabkan unsur-unsur budaya tradisi ada yang hilang, namun sebaiknya ada aspek budaya baru yang timbul. Fenomena transformasi budaya masyarakat Melayu selama ini berlangsung sesuai kerangka aturan adat yang fleksibel, dalam menyikapi perubahan zaman masih bisa diterima. Implikasi dari hasil penelitian dalam beberapa kasus terlihat ada kecenderungan bahwa rumah tinggal yang dirujuk adalah jenis rumah panggung tipologi I dan II, sebagai "identitas tradisional." Sedangkan untuk bangunan rumah tinggal "identitas modern" adalah rumah panggung tipologi atau langgam III, ini lebih variatif, monumental dan formal. Selanjutnya pada beberapa bangunan terlihat struktur bangunan tradisi tidak menyatu dengan bangunan struktur modern. Terkesan nilai ragam hias atau ukiran ornamen cenderung banyak perubahan terutama yang bernilai sakral, mistis dan religius. Pada hakekatnya tradisi Melayu adat Melayu merumuskan ada : "tiga simbolik" yang tergambar dalam rumahnya yakni: status yang terdapat dalam hirarki kehidupan masyarakat, kedudukan, ruang, dan peraturan larangan (tabu).
\end{abstract}

Kata Kunci: perubahan, masyarakat melayu, tradisi.

\begin{abstract}
This research was conducted to prove the changes in Malay society by studying the tradition of building houses, in the city of Medan, North Sumatra. The study used a qualitative descriptive method with an ethnomethodology and ethnoscience design, using 10 research subjects on stilt houses. This research instrument uses documentation and interview techniques which comprehensively want to see the cultural phenomenon of the Malay community in the city of Medan, in relation to the tradition of building houses. The results of the data analysis technique used by the Miles and Huberman model show that the change in the shape of the traditional house is caused by the Malay traditional factor which provides openness and flexibility. The changes in the Malay community in the city of Medan have caused the elements of traditional culture to be lost, but it is better that there are new cultural aspects that arise. The phenomenon of cultural transformation of the Malay community so far has taken place according to a flexible framework of customary rules, in responding to changing times it is still acceptable. The implication of the research results is that in some cases there is a tendency that the houses referred to are types of houses on stilts typology I and II, as "traditional identities." As for residential buildings, "modern identity" is a typology or style III stilt house, which is more varied, monumental and formal. Furthermore, in some buildings, it can be seen that traditional building structures are not integrated with modern structures. Impressed with the value of decorative or ornamental carvings tend to change a lot, especially those of sacred, mystical and religious value. In essence, the Malay tradition of traditional Malay formulates that there are: "three symbols" depicted in the house, namely: the status contained in the hierarchy of people's lives, position, space, and prohibition rules (tabu).
\end{abstract}

Keywords: change, malay society, tradition.. 


\section{PENDAHULUAN}

Masyarakat Melayu sebagai suatu suku bangsa yang ada di Sumatera Utara sejak dahulu sudah membentuk, mengembangkan adat tradisi, dan kebiasaan-kebiasaan yang menjadi kebutuhan dasarnya. Salah satu dasar adalah tempat tinggal atau rumah. Dengan berkembangannya kebudayaan Melayu maka tempat tinggal yang dahulu fungsinya hanya sebagai tempat berlindung dari bencana alam, sedikit demi sedikit diduga bergeser maknanya menjadi tempat untuk beraktivitas dan bersosialisasi. Menurut Heidekrueger (2017), adanya kapak tua atau beliung, asumsinya benda itu sebagai hasil budaya yang dibuat dan dibawa oleh orang Asia tengah ke area pulau-pulau Melayu.

Sedangkan Marsden (1994) lebih mengarahkan Melayu itu ke etnolinguistik yang memperlihatkan kesamaan bahasa yang digunakan oleh masyarakat se Nusantara, Mikronesia, Melanesia dan Polinesia dengan bahasa ibunya Austronesia. Terkait dengan ras dan bahasa serumpun itupun dikuatkan Tabrani (1995), masingmasing ras dan bahasa mereka gunakan sampai kini, bahwan ada persamaan bahasa serumoun termasuk warna kulitnya. Yang membuat berbeda satu dengan lainnya adalah aneka ragam budaya yang berkembang sejak adanya migrasi 2500 SM yakni zaman Paleoliticum dan Mesoliticum. Dari kedua periode itu munculah ras Melayu Proto, yang kemudian mengalami migrasi ke dua tahun 1500 SM ke zona yang sedikit lebih maju yakni Melayu Deutro. Masyarakat Melayu ini sudah banyak membangun rumah tinggal yang tetap di daerah pinggiran sungai atau lembah yang subur, hidup berkelompok umumnya bertahan hidup bertumpu pada dua sumber yakni pertanian dan sebagai nelayan. Dari uraian di atas dapat diasumsikan awal mula Melayu di Asia Tenggara berperadaban hingga leluhur etnis Melayu yang kini ada di Indonesia, termasuk Sumatera Utara tepatnya kota Medan sudah ada aneka budaya tradisinya. Secara turun temurun tradisi budaya masih mempertahankan nilai-nilai simbolik dan makna tertentu yang universal yakni mendirikan rumah sebagai tempat tinggalnya. Nilainilai universal yang dimaksudkan dalam mendirikan rumah sebagai tempat hunian berkelompok tersebut tidak terlepas dari bentuk bangunan vernakuler yang di dalamnya ada unsur makna religius (keagamaan). Bangunan bersifat Vernakuler (dalam Tambunan, 2015) masyarakat Melayu dikenal dengan konsep desain yang khusus (tipologi atau langgam). Adapun fenomena masyarakat Melayu dahulu dengan sekarang sungguh sangat kontras dalam membangun rumah tinggal. Secara tipe rumah tinggal Melayu dahulu dikenal dengan prinsip teguh berpegang adat istiadat, status sosial dan semangat gotong royong dalam kehidupan sosialnya. Ciri khas rumah tinggal Melayu tradisional itu tata letak lokasinya pada awalnya banyak berdiri di sekitar pinggiran sungai meluap yang rawan banjir atau dengan area pantai yang air pasang laut sering kali naik ke daratan.

Menyikapi adanya bencana alam dengan mengutamakan keselamatan (savety) maka kebiasaan untuk bertahan (survive) komunitas setempat membangun rumah di atas ketinggian minimal setinggi lutut orang dewasa di kala berdiri. Maka konsep rumah harus berbentuk panggung, ditopang tiang-tiang utama yang kokoh dari jenis kayu tertentu. Istilah rumah panggung menjadikan pilihan gaya arsitektur vernakuler yang melekat hingga beberapa decade, , sebelum adanya pergeseran (perubahan) yang secara evolusi terkait struktur sosial budaya Melayu Deli. Dalam pandangan Radcliffe (2013) dikutip Koentjaraningrat (1980) bahwa; yang menggeser struktur sosial budaya suku di Indonesia bukan pemuas kebutuhan individu melainkan kebutuhan sosial kelompoknya. yang banyak berhiaskan ornamen baik yang dilukis maupun diukir menunjukkan orang itu sangat terhormat dan terpandang di lingkungan sekitarnya.

Hunian vernakuler yang dimaksud dalam penelitian ini adalah rumah tinggal yang berada di lingkup wilayah teritorial kesultanan Deli. Sebaran rumah tersebut dahulunya adalah Kampung Medan yang didirikan Guru Patimpus tahun 1590an. Adapun lokasi penelitian ini ditentukan sekitar Jalan Puri, Jalan Halat, Jalan Amaliun dan Jalan Rahmadsyah ditambah beberapa rumah lainnya di tempat berbeda. Pada saat observasi ke lapangan ditemukan sekitar 10 bangunan dengan kondisi yang sudah sulit dalam keadaan baik, beberapa subjek sudah rusak dan berubah dari material dan orisinalitasnya. Dengan demikian kondisi kearifan lokalnya juga akan semakin lenyap akibat zaman yang berkembang seiring tata kelola pemerintahan kota, konsekensinya bangunan ini harus diteliti spasial karakternya.

Adapun tujuan mengalisa karakter spasial itu rumah panggung di kota Medan ini menyangkut perumusan masalah antara lain langgam (tipologi), perpaduan budaya, hirarki pola dan ruangan serta ornamen dikaji secara makna simboliknya. Diharapkan dengan memakai metode penelitian deskriptif kualitatif dengan tahapan dokumentasi dan wawancara secara mendalam, ke seluruhan total sampelnya. Hasilnya pengumpulan data akan diolah berdasarkan 3 alur cara Miles (1972) tersebut akan disimpulkan melalui premis 
temuan dideskripsikan dalam model skema tafsir secara emik. Untuk melihat tiga alur model Miles dan Huberman itu ditempuh analisa yakni: 1. Menanyakan langsung kepada pemilik rumah untuk mengungkap makna dan fungsi langgam. 2. Menempuh cara refleksi untuk spasial perpaduan budaya (sikap dan ucapan serta prilaku). 3. Merangkai kaitan hirarki pola dan ruang terhadap ornament dari sisi makna dan simboliknya. Untuk menemukan keseluruhan substansi baik fungsi maupun tata kelolanya perubahan tradisi akan dipakai model analisa kualitatif etnosains.

Pada masa awal bahwa masyarakat Melayu yang menganut paham animisme dan dinamisme diperkirakan punya konsep hunian dalam membina interaksi antar anggota keluarga dan kelompoknya. Bertambah besarnya jumlah anggota keluarga dan kelompoknya menjadikan konsep hunian mengalami peralihan, termasuk perubahan kepercayaan, dari paham takhayul ke paham baru. Masuknya paham baru seperti agama Hindu - Budha, Islam, dan Kristen ikut pula merubah cara - cara membangun rumah tinggal dari takhayul ke paham hukum kausalitas. Hal ini dipertegas pula oleh Husny, Husny (1980: 61) mengatakan bahwa:".... masyarakat Melayu telah memiliki akar budaya membangun rumah tinggal dengan memakai pola hunian berbanjar dan berpencar terbuka untuk mendapatkan sistem tanggungjawab kolektif (collective responsibility)”. Struktur masyarakat Melayu agraris biasanya hidup berkelompok yang berkeinginan hidup bersama dalam satu wilayah hunian, yang aman, tolong menolong, dan menjalin bersilaturahim.

Perubahan sosial masyarakat Melayu Deli terdiri dari kategori struktur dan pola hubungan keluarga, agama, ekonomi dan politik tetap mempertahankannya. Selanjutnya perubahan budaya masyarakat Melayu Deli Sumatera Utara terjadi dalam sistem ide dan nilai yang dimiliki bersama (kelompok). Dampak dari perubahan itu ditambah lagi perubahan lingkungan fisik dan demografi (komposisi etnis) mempengaruhi migrasi orang Melayu Deli (Sumatera Timur). Perubahan ini secara simultan ikut pula menggerus struktur seperti yang di ilustrasikan Pelly (2019), seperti; aturan-aturan, tata kerama, adat-istiadat, nilainilai, teknologi, ilmu pengetahuan, estetika dan kesenian.

\section{KAJIAN TEORI}

\section{Migrasi Rumah Panggung dan Perkotaan}

Perubahan lingkungan fisik dan demografi setidaknya di era akhir abad ke 19 dan awal abad ke 20 gelombang migrasi pemerintahan kolonial Belanda yang menguasai lahan pertanian. Ketika itu banyak perkebunan mendatangkan pebisnis Eropa dan buruh perkebunan Tembakau di Sumatera Timur. Kedatangan orang Cina (pedagang) dan Jawa (buruh) sebagai kuli kontrak juga berdampak kepada demografi terutama suku Melayu menjadi minoritas. Secara politis selama berlindung di bawah kesultanan Deli, kedudukan suku Melayu begitu kuat. Tetapi adanya Belanda yang menguasai lahan perkebunan dan membuat perjanjian, maka peranan kekuasaannya juga dipersempit. Sementara secara kultural orang Melayu merasa kehilangan tradisi lahan pertanian komoditi ekspor menjadi kultur tanah jaluran yang menghasilkan padi dan palawija.

Kondisi ikut mempercepat pembusukan tradisi punya tahan luas sehingga bisa mendirikan rumah tinggal (rumah panggung) lengkap. Secara ekologis orang Melayu Deli juga tidak sanggup mengatasi serangan pemburu tanah dari suku Batak, Mandailing, Padang, India dan Arab. Banyak lokasi yang dahulu didominasi orang Melayu sedikit demi sedikit beralih, akhir mereka terdesak ke daerah pesisir. Termasuk perkembangan kota menjadi pusat bisnis baru perdagangan, jasa dan pertukangan yang bukan impian buat sebahagian kerabat orang Melayu Deli. Demikian pula apabila kita kaji tentang kehidupan masyarakat Melayu Sumatera Utara umumnya dan kota Medan khususnya, berdasarkan historisnya adalah suatu komunitas yang hidup atau bertempat tinggal di kawasan Sungai Deli dan Sungai Babura. Suatu daerah yang dahulu didirikan oleh Guru Patimpus adalah sebuah kampung kecil, yang terus berkembang ketika Nienhuis (Belanda) menjadikan Medan Putri sebagai pemerintahan dan pusat perdagangan di jaman kolonial. Kini namanya berubah menjadi 'Medan' masih menyisakan beberapa bangunan rumah tinggal Melayu tradisional.

Uniknya bangunan rumah tradisional Melayu ini masih sanggup bertahan dan berdiri, hanya saja kondisinya sudah sangat memperihatinkan karena beberapa konstruksinya sudah termakan usia. Kalau ditelusuri dari artefak rumah tinggal Melayu ini banyak hal - hal yang perlu dipelajari. Dari sini dapat diketahui cara masyarakat Melayu dalam mendirikan rumah tinggal ini telah memiliki kebudayaan Melayu yang tidak primitif. Mereka telah mempunyai konsep atau pola yang umumnya menyiratkan kearifan budaya dan kenyaman bila tinggal di dalamnya.

Konstruksinya yang didominasi oleh material kayu selalu dirancang dengan sengaja membuat rumah dengan tiang yang tinggi, sehingga di bagian bawahnya 
berguna untuk tempat beraktivitas yang lain. Jadi rumah masyarakat Melayu tradisional ini banyak dijumpai ruang terbuka atau kolong, terlihat pula susunan anak tangga menuju ruang atas rumah atau serambi terangkum suatu nilai adat yang sangat agung dan pantas dibanggakan. Rumah panggung adalah salah satu konsep cara membangun rumah tinggal yang telah menyesuaikan konstruksi dengan lingkungan alamnya.

Dalam artikel ini akan diupayakan melihat lebih jauh tentang aktivitas masyarakat Melayu Medan dalam membangun rumah tinggal. Kehidupan di kota selalu membawa dampak terhadap konsekuensi terutama keberadaan berdirinya rumah panggung yang sangat padat penduduknya. Kota Medan yang penduduknya sangat multi etnis ini dahulu didominasi oleh suku Melayu mulai terdesak oleh suku lainnya seperti Batak, Mandailing, Karo, Nias, dan suku pendatang dari Minangkabau, Jawa, Arab, India dan, Cina.

Hal ini tentunya akan membuka suatu transformasi budaya antar suku termasuk terjadinya perubahan dalam semua struktur sosial kehidupan masyarakat. Perubahan budaya Melayu tergambar dalam bentuk peralihan beberapa konsep membangun rumah tinggal, pada masa lalu dengan semangat gotong royong, kini lebih bersifat individual. Bentuk bangunan juga ikut bergeser dari rumah tiang tinggi menjadi rumah tanpa kolong lagi, karena sudah disulap menjadi ruang untuk fungsi lainnya.

Masyarakat Melayu Medan dilihat dari mata pencaharian adalah para petani dan nelayan yang menurut Geertz (2005: 32) pernah pula mengatakan bahwa:"...masyarakat Melayu adalah 'agraris'. Masyarakat yang hidup secara komunal dan tidak mengenal sikap hidup individual. Namun, demikian sebenarnya masyarakat agraris sangat gamang dalam menjalani kehidupan modern yang serba industri”. Masyarakat Melayu Medan walaupun tergolong agraris bahwa kultur masih memiliki pentingnya unsur 'budaya tanah'.

Seperti ungkapan Sinar (2003: 4) bahwa “....Beramu tak merusak kayu Berkebun tak merusak dusun, Berotan tak merusak hutan, Berkampung tak merusak gunung, Bergetah tak merusak rimba, Berumah tak merusak tanah, Berladang, tak merusak padang”. Artinya dalam mendirikan bangunan jangan sampai mengganggu 'filosofis tanah' yang dianggap sebagai tempat lahir, tempat hidup, sekaligus tempat untuk mati. Faktor keseimbangan menjadi prioritas suku Melayu dalam mendirikan rumah, sebelum rumah ada harus terlebih dahulu diperiksa 'aura' nya untuk lokasi (tempat).

Demikian pula persyaratannya untuk memilih material kayu, ukurannya, jenisnya dan sebagainya diatur dalam adat tradisi. Tanah bukan hanya begitu sakral tapi dianggap memiliki mitos tersendiri pula.

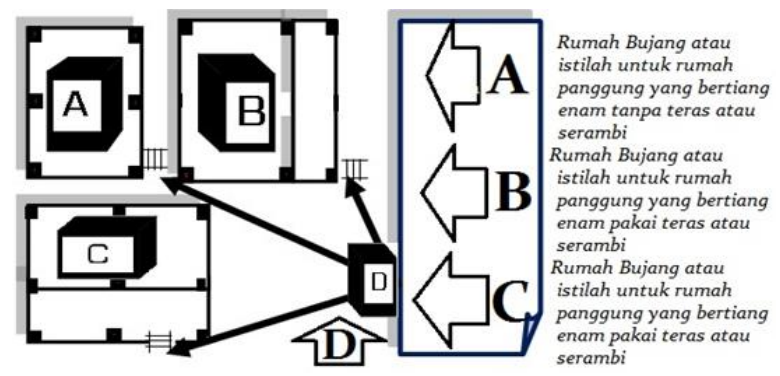

Gambar 1. Pola dan Arah Pintu Masuk Model Rumah Panggung pada Saat Pembangunnya

Masyarakat Melayu telah menjadikan tanah dan rumah tinggal menggambarkan tiga simbolik yakni: identitas sosial, susunan ruang dan peraturan pelarangan (tabu). Kota Medan dahulunya adalah sebuah kampung kecil yang terletak, pada pertemuan dua buah sungai yaitu Sungai Deli dan Sungai Babura. Karena letaknya yang dekat dengan sungai dan strategis oleh pemerintah zaman Belanda, kampung yang terletak di atas tanah datar yang ketika itu hanyalah dihuni oleh lima puluh buah rumah saja, dijadikan pusat pemerintah sekaligus daerah pusat perdagangan.

Pada masa itu daerah ini sempat dijuluki sebagai Paris van Sumatera dan setelah masa kemerdekaan kawasan Medan berubah menjadi Medan Area, dan sekarang ini cukup populer dengan sebutan Medan yang hari jadinya diperingati setiap tanggal 1 Juli 1590.

Perkembangan kota Medan begitu pesat sejak pemerintah kolonial membuka perkebunan yang dipelopori oleh Nienhuys pada tahun 1862. Ketenaran daerah Deli inipun sampailah ke Eropa. Adanya pertumbuhan perkebunan membuat kawasan Sungai Deli sampai Glugur serta Jalan Patimpus terus Petisah sekarang ini, adalah tempat atau kawasan pusat perekonomian sekaligus pusat pemerintahan, bagi Kerajaan Deli dan Keresidenan Sumatera Timur.

Kini kota Medan sudah menjadi sebuah pemukiman yang sangat padat karena penduduknya sudah mencapai angka 2 juta jiwa lebih berdasarkan catatan BPS 2003 Sumatera Utara, Medan dalam Angka. Kota Medan didirikan oleh Guru Patimpus, yakni nenek moyang Datuk Hamparan Perak (Dua Belas Kuta) dengan Datuk Suka Piring. Menurut ceritanya Guru 


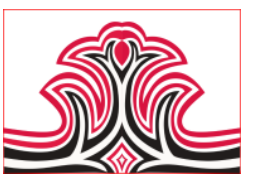

Patimpus ini adalah bermarga Sembiring yang memulai membangun Medan sebagai perkampungan sejak tahun 1643.

Secara fisik geografis letak kota Medan adalah salah satu dari sekian kota yang ada di Indonesia yang terletak di antara dua sungai. Sebagai belahan utama sungai Deli dan belahan lainnya adalah sungai Babura, adalah potret umum masyarakatnya yang hidup di lokasi tanah yang subur sekaligus memanfaatkan jasa sungai sebagai sarana transportasi dan transaksi ekonomi pada waktu itu. Di kawasan ini pulalah banyak bermunculan rumah - rumah tinggal penduduk, gedung perkantoran, dan toko-toko yang berdiri. Umumnya arsitekturnya sangat dipengaruhi oleh gaya Eropa (Belanda) dan Asia.

Mengingat yang pada masa awal masyarakat Melayu menganut paham animism dan dinamisme itu menyebabkan adanya konsep hunian dalam menjaga interaksi antar anggota kelompoknya. Bertambah besarnya anggota kelompoknya menjadikan konsep hunian bertransisi dari mistis (takhayul) ke konsep keagamaan, seperti Hindu, Budha, Islam, dan Kristen. Perpaduan budaya dari tradisi dan masuknya paham baru yang datang dari luar ikut pula merubah konsep budaya lokal dengan budaya luar.

Hal itu diuraikan oleh Husny (1976) masyarakat Melayu Deli punya pola hunian tersendiri dengan dua konsep yakni berbanjar dan berpencar terbuka. Untuk mendapatkan status sosial tanggungjawab bersama (collective responsibility) struktur masyarakat Melayu agraris biasanya hidup berkelompok, yang berkeinginan hidup bersama dalam satu area hunian yang bersifat nyaman, aman, asri, tolong menolong dan mudah berkomunikasi antar keluarga maupun kerabatnya.

Adapun yang melatarbelakangi penelitian ini terinspirasi dengan adanya asumsi sementara bahwa aktivitas masyarakat Melayu Deli sejak lama telah mempunyai tata kelola spesifik dalam konsep hunian (membangun rumah tinggal). Diduga telah terjadi pergeseran budaya dan transisi (perubahan) membangun rumah panggung, termasuk upaya pelestariannya. Adapun kejelasan kepastian terukur bagaimana sesungguhnya kedua asumsi itu dapat dibuktikan tentu akan dilakukan langkah-langkah riset yang diperlukan di lapangan.
Gorga : Jurnal Seni Rupa

Volume 10 Nomor 02 Juli-Desember 2021 p-ISSN: 2301-5942 | e-ISSN: 2580-2380

\section{METODE PENELITIAN}

Penelitian ini merupakan penelitian kualitatif, Metode penelitian kualitatif adalah penelitian yang digunakan untuk menyelidiki, menggambarkan, menjelaskan, menemukan kualitas atau keistimewaan dari pengaruh sosial yang tidak dapat dijelaskan, diukur atau digambarkan melalui pendekatan kuantitatif. Metode ini digunakan untuk meneliti pada kondisi obyek yang alamiah, (sebagai lawannya eksperimen) di mana peneliti adalah sebagai instrumen kunci. Pengambilan sampel sumber data dilakukan secara purposive dan snowball, teknik pengumpulan dengan tri-anggulasi (gabungan), analisis data bersifat induktif atau kualitatif dan hasil penelitian kualitatif lebih menekankan arti dari pada generalisasi.

\section{HASIL DAN PEMBAHASA}

\section{Hasil}

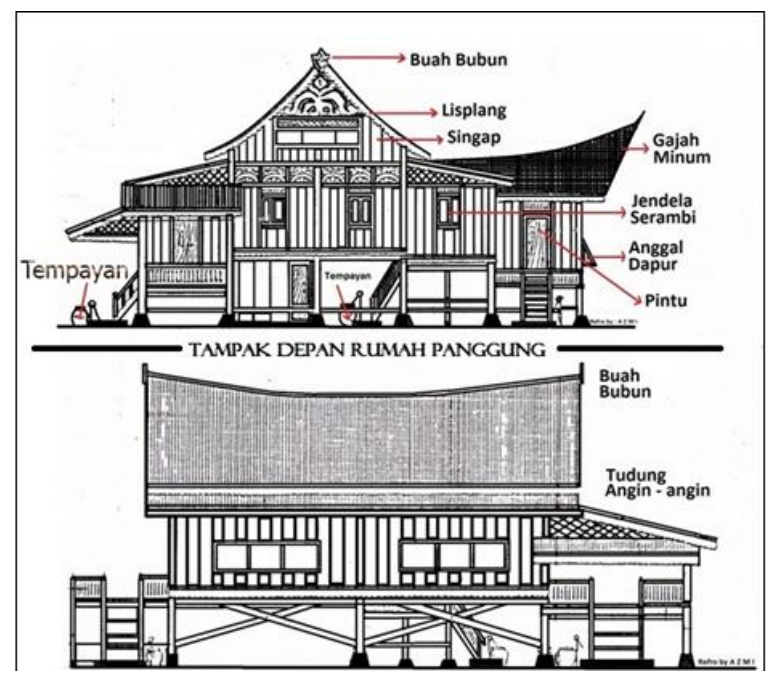

Gambar 2. Tampak Samping Rumah Panggung

Tabel 1. Bangunan Rumah Tinggal Studi Kasus di Kota Medan

\begin{tabular}{|c|c|c|c|}
\hline \multicolumn{4}{|c|}{ BANGUNAN RUMAH TINGGAL STUDI KASUS DI KOTA MEDAN } \\
\hline No. & $\begin{array}{l}\text { JENIS RUMARH } \\
\text { TINGGAL }\end{array}$ & $\begin{array}{l}\text { BENTUR, CIRI-CIRI, } \\
\text { PERUBAHANNYA }\end{array}$ & $\begin{array}{l}\text { ORNAMEN, POSISI DAN } \\
\text { MAKNA SIMBOLIK }\end{array}$ \\
\hline 1. & $\begin{array}{l}\text { Rumah panggung tiang kayu Jl. } \\
\text { Puri No.100 Medan }\end{array}$ & 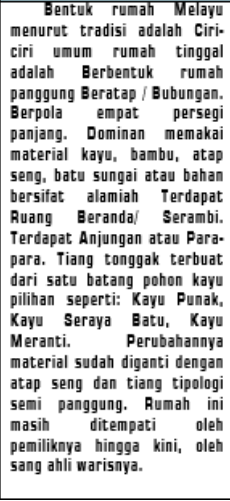 & 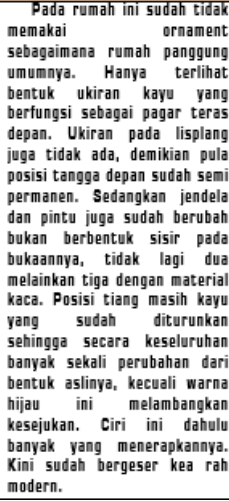 \\
\hline
\end{tabular}




\begin{tabular}{|c|c|c|c|}
\hline 2. & & 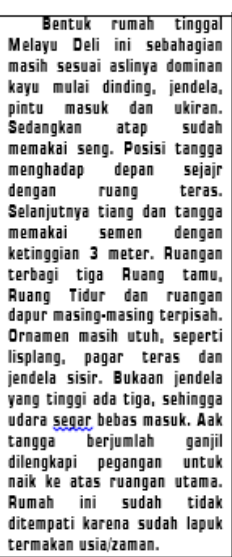 & 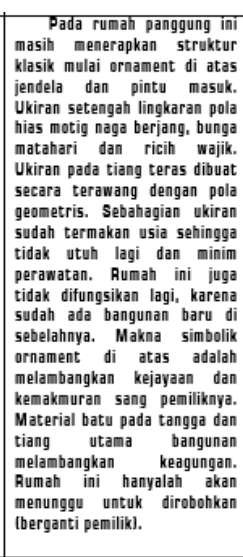 \\
\hline 3. & & 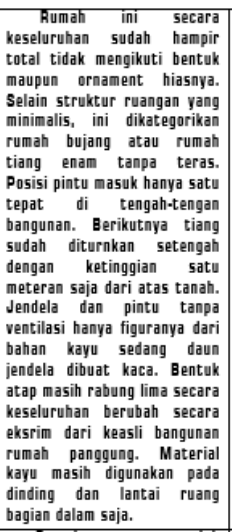 & 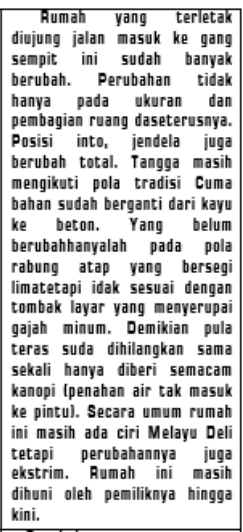 \\
\hline 4. & & 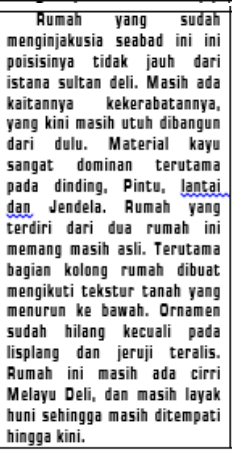 & 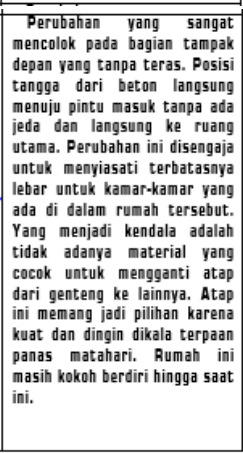 \\
\hline 5. & $\begin{array}{l}\text { Rumah Panggung tiang batu } \\
\text { Jl. Brigien Katamso Medan }\end{array}$ & 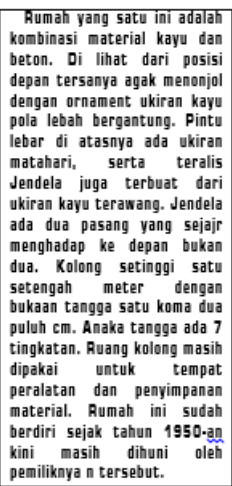 & 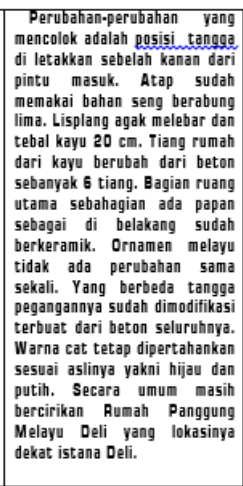 \\
\hline
\end{tabular}

Gorga : Jurnal Seni Rupa

Volume 10 Nomor 02 Juli-Desember 2021 p-ISSN: 2301-5942 | e-ISSN: 2580-2380
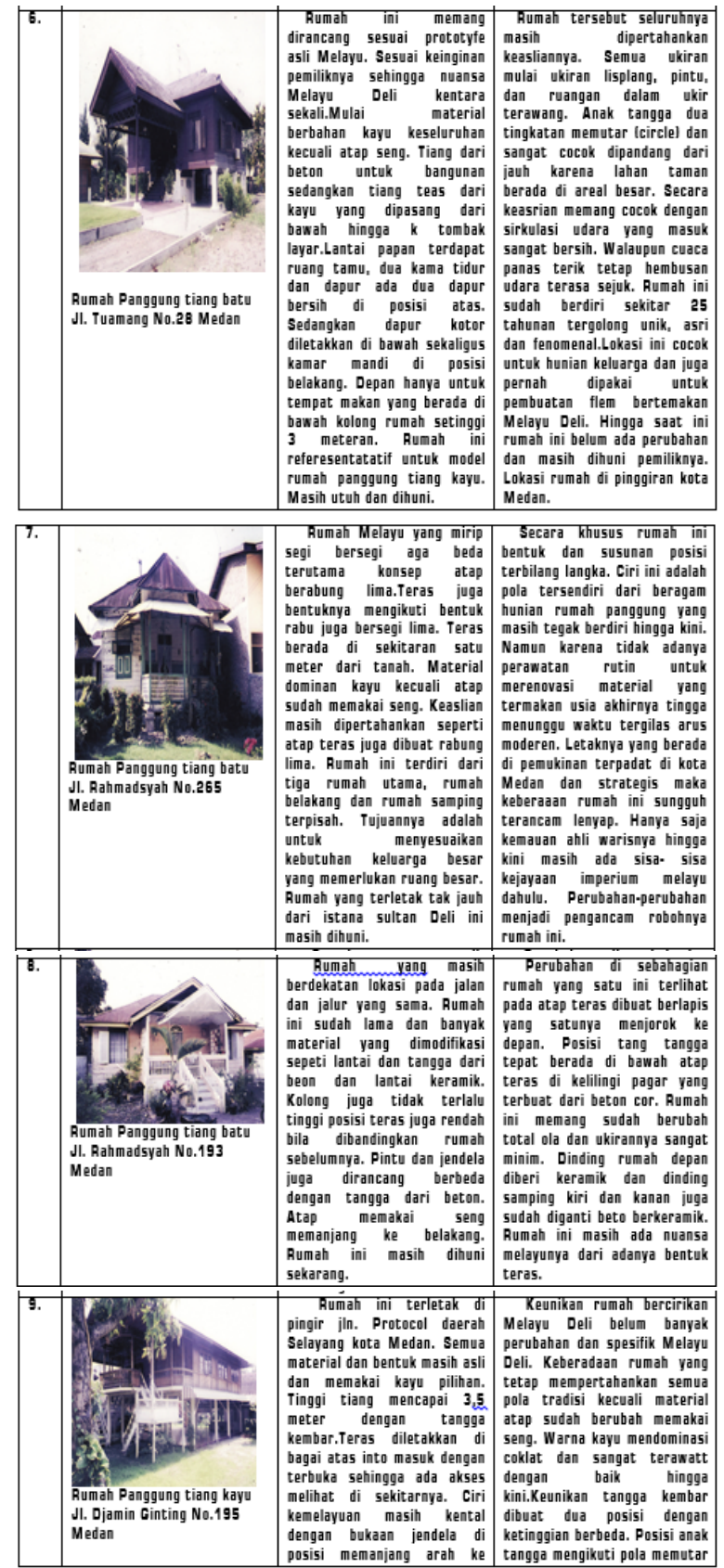

Rumah ini terletak di Keunikan rumah bercirikan pingir jin. Protocol daerah Melayu Deli belum banyah material dan bentuk masih asli Deli. Keberadaan rumah yang dan memakai kayu pilihan. tetap mempertahankan semua meter dengan tanga atap sudah berubah memakai kembar.Teras diletakkan di seng. Warna kayu mendominasi bagai atas into masuk dengan coklat dan sangat terawatt terbuka sehingga ada akses dengan baik hingga melihat di sekitarnya. Ciri $\begin{aligned} & \text { kini.Keunikan tangga kembar } \\ & \text { kemelayuan }\end{aligned}$ $\begin{array}{lll}\text { kemelayuan masih kental } & \text { dibuat dua posisi dengan } \\ \text { dengan bukaan jendela di } & \text { ketinggian berbeda. Posisi anak }\end{array}$ dengan bukaan jendela di
posisi memanjang arah $\mathrm{ke}$

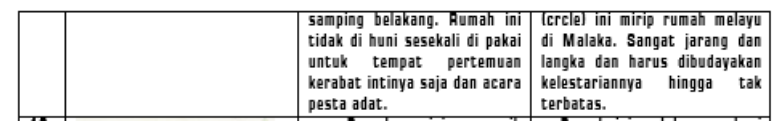

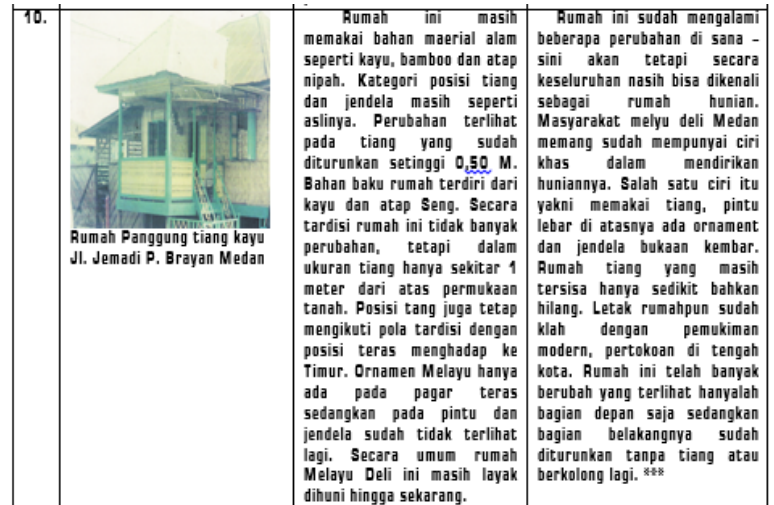




\section{Pembahasan}

Penelitian ini menghimpun dan menganalisis aspek bentuk, ciri-ciri, perubahannya, ornamen posisi dan makna simboliknya. Secara keseluruhan subjek penelitian 10 rumah panggung (hunian) yang diteliti, menunjukkan dominan tidak lagi bentuk aslinya. Beberapa material kayu masih bertahan terutama pada dinding, lantai, tiang, pigura jendela, pagar teras. Sedangkan tangga sudah berbahan beton, selanjutnya atap tidak dari bahan nipah tetapi dari bahan seng.

Istilah Melayu sebagai ras bermula dari perkataan Melieu $=$ me-liau $=$ me-lie-au $=$ me-liea-u. Lalu dalam penjelasan Adenansyah (1989) didefenisikan menjadi kata melayu yang artinya "agung dan kebanggaan". Orang Melayu identik dengan sangat patuh pada kebudayaannya dan bangga disebut bila patuh pada tradisi yang berlandaskan spirit agama (religius). Prinsip orang Melayu dahulu selalu berpegang pada petuah leluhur (dalam Effendy, 2004) bahwa: "Tanda orang bertuah, hidup berumah dan berhutan tanah". Kiasan pepatah ini cenderung kepada konteks belumlah sempurna dikatakan seseorang itu dalam kehidupannya, kalau tak punya rumah, kerabat/keturunan/pasangan hidup, dan harta berupa tanah.

Menurut Highhouse (2003: 10) menyatakan bahwa:"....kondisi alamnya yang dibelah oleh dua sungai itulah merupakan cikal bakal lahirnya masa kejayaan kerajaan Deli yang pernah berkuasa dari abad ke tiga belas hingga abad ke lima belas ini sudah punya konsep pemukiman dengan bentuk rumah panggung berdiri di kiri dan kanan sungai". Pengaruh alam ini pula yang mempengaruhi kebudayaan masyarakat Melayu di Sumatera Timur ini. Hal ini terlihat pada sistem perkampungan, pengangkutan, dan arsitektur rumah tinggal mereka yang berbentuk bangunan bertiang tinggi.

Kini bekas peninggalan bangunan-bangunan lama seperti gedung kantor, rumah tinggal masih dapat ditemui dan kondisinya sudah dirubah dari aslinya, namun atapnya berbentuk sampan atau perahu, umumnya material fisik bangunan sudah baru. Rumahrumah tempat tinggal maupun bangunan kantor dahulu umumnya terdapat dalam satu komplek hunian, seperti berdirinya rumah dalam beberapa deretan - deretan yang memanjang secara terpisah mengikuti alur sungai.

Jarak antara rumah yang satu dengan yang lainnya kirakira 2 meter, menghadap matahari terbit, dan di depannya terdapat jalan. Rumah dibangun berhadaphadapan dan bertolak belakang. Ada lahan pertanian yang disebut kebun yang ditanami dengan tumbuhan berusia panjang seperti pohon mangga, jeruk, durian dan kelapa. Demikian pula lumbung tempat penyimpanan padi dibuat dibelakang rumah tempat tinggal.

Menelaah antara rumah yang satu dengan yang lainnya kira-kira 2 meter, menghadap matahari terbit, dan di depannya terdapat jalan. Rumah dibangun berhadaphadapan dan bertolak belakang. Ada lahan pertanian yang disebut kebun yang ditanami dengan tumbuhan berusia panjang seperti pohon mangga, jeruk, durian dan kelapa. Demikian pula lumbung tempat penyimpanan padi dibuat dibelakang rumah tempat penyimpanan.

Susunan tiang ini sangat perlu diamati mengingat ciri menunjukkan langgam rumah panggung yang ada di kota Medan. Rumah tiang identik dengan istilah rumah yang akan didirikan itu untuk siapa peruntukannya. Jadi secara visual bila melihat dari banyak jumlah tiang masyarakat lokal akan tahu yang menghuninya rumah itu tanpa bertemu langsung dengan sipemiliknya. Dari dominasi tiang juga akan menyiratkan posisi status keluarga dan juga penyesuaian penempatan simbol (penanda).

Demikianlah secara ringkas membicarakan tentang "rumah tiang" atau "rumah panggung" dari letak dan posisi hadapan rumah yang didirikan. Kebiasan ini sudah berlangsung secara tradisi lokal (local wisdom) tanpa ada yang mengetahui data sejak kapan itu berawal.

\section{KESIMPULAN DAN SARAN}

\section{Kesimpulan}

Berdasarkan beberapa studi kasus bangunan rumah tinggal di kota Medan terdapat pergeseran budaya dan perubahan bentuk konstruksi dari beberapa langgam I, II, dan III. Bentuk langgam I dan II masih masih mempertahankan adat tradisi Melayu yakni nilai universal sebagai identitas tradisional. Sedangkan bangunan langgam III sudah memberikan keluwesan dan keterbukaan budaya dari unsur-unsur lain, sehingga terjadi akulturasi budaya di dalam masyarakat Melayu. Perubahan nilai adat tradisi ini belum ada yang bertentangan dengan filsafat, mitos dan religius maupun hukum syarak agama Islam.

\section{Saran}

Perubahan masyarakat Melayu dalam mendirikan rumah tinggal Melayu di kotamadya Medan, justru sanggup menciptakan serta mempertahankan sekaligus mengembangkan nilai universal adat Melayu yang ada. 


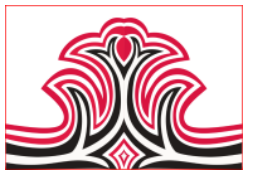

Kearifan budaya lokal, kenyaman di dalamnya, serta nilai eksotis arsitektur masih dapat bertahan hingga kini, walaupun masih ada sedikit kekurangserasian dalam penerapan unsur tradisional seperti: letak rumah, serambi, tangga, tiang, fungsi ruang dipadukan dengan unsur modern.

\section{DAFTAR RUJUKAN}

Adenansyah, T. (1989). Butir-butir Sejarah Suku Melayu Pesisir Sumatera Timur. Medan: Yayasan Karya.

Radcliffe-Brown, A. R. (2013). The andaman Islanders. Cambridge University Press.

Effendy, Tenas dan Mudra, Al Mahyudin. (2004). Rumah Melayu Memangku Adat dan Menjemput Zaman. Yogyakarta : AdiCita.

Geertz, C. (2005). Clifford Geertz by His Colleagues. USA: University of Chicago Press.

Highhouse, S., Lievens, F., \& Sinar, E. F. (2003). Measuring Attraction to Organizations. Educational and psychological Measurement, 63(6), 986-1001.

Heidekrueger, P. I., Ninkovic, M., Heine-Geldern, A., Herter, F., \& Broer, P. N. (2017). End to-end Versus End-to-Side Anastomoses in Free Flap Reconstruction: Single Centre Experiences. Journal of plastic surgery and hand surgery, 51(5), 362-365.

Marsden, J. E., \& Hughes, T. J. (1994). Mathematical Foundations of Elasticity. New York: Courier Corporation.

Husny, M. Lah. (1976). Bentuk Rumah Tradisional Melayu. Medan: BP Husny.

Koentjaraningrat. (1980) Sejarah Teori Antropologi I. Jakarta: UI Press.

Miles, Mathew, B. dan Huberman, A. Michael. (1972). Analisa Data Kualitatif. Jakarta : UI Press.

Pelly, Usman (2019) Orang Melayu dalam Kehidupan Kota Medan, dalam "Tak Melayu Hilang di Bumi. Medan: Casa Mesra.

Tambunan, Syahfitri. (2015). Arsitektural Vernakuler dari Rumah Panggung Indonesia. www. Analisadaily.com (diakses tanggal 19 September 2020).

Tabrani, Primadi. (1995). Belajar dari Sejarah dan Lingkungan. Bandung: Penerbit Institut Teknologi Bandung. 